\title{
Optimization of media composition for the production of biohydrogen from waste glycerol
}

\author{
Rujira Jitrwung, Viviane Yargeau* \\ Department of Chemical Engineering, McGill University, 3610 University Street, Montreal, QC, Canada H3A 2B2
}

\section{A R T I C L E I N F O}

Article history:

Received 7 March 2011

Received in revised form

11 May 2011

Accepted 13 May 2011

Available online 22 June 2011

Keywords:

Hydrogen

Enterobacter aerogenes

Glycerol

Box-Behnken design

\begin{abstract}
A B S T R A C T
Enterobacter aerogenes has a known ability to convert glycerol during a fermentative process to yield hydrogen and ethanol as the main products. A Box-Behnken design and response surface methodology were used to determine the optimal concentration of some media constituents and oxygen to maximize the yield of biohydrogen. Results indicated that the concentration of the salts studied: $\mathrm{NH}_{4} \mathrm{NO}_{3}, \mathrm{FeSO}_{4}$, and $\mathrm{Na}_{2} \mathrm{HPO}_{4}$ and; the presence of oxygen in the pre-culture significantly influence the production of biohydrogen. Optimal conditions were determined to be $7.5 \% \mathrm{O}_{2}$ in the inoculum transfer step, ratio of inocula $18 \%, 8 \mathrm{~g} / \mathrm{L}$ of $\mathrm{Na}_{2} \mathrm{HPO}_{4}, 0.00625 \mathrm{~g} / \mathrm{L}$ of $\mathrm{FeSO}_{4}$ and $1.5 \mathrm{~g} / \mathrm{L}$ of $\mathrm{NH}_{4} \mathrm{NO}_{3}$. These optimal conditions resulted in a measured yield of $0.85 \mathrm{~mol} \mathrm{H}_{2} / \mathrm{mol}$ glycerol at a substrate concentration of $15 \mathrm{~g} / \mathrm{L}$ and a maximum predicted yield of $0.95 \mathrm{~mol} \mathrm{H}_{2} / \mathrm{mol}$ glycerol at a substrate concentration of $21 \mathrm{~g} / \mathrm{L}$. These results were obtained using lower concentrations of salts than in previous studies, corresponding to a $76 \%$ cost savings. These experimental results also demonstrated the importance of optimizing the amount of oxygen present in the biological system rather than maintaining complete anaerobic conditions.
\end{abstract}

Copyright $\odot$ 2011, Hydrogen Energy Publications, LLC. Published by Elsevier Ltd. All rights

reserved.

\section{Introduction}

Due to environmental concerns and decreasing fuel reserves, biodiesel is being increasingly used as a substitute for diesel oil. During biodiesel production, each mole of oil reacts with $3 \mathrm{~mol}$ of alcohols (such as methanol or ethanol) yielding $3 \mathrm{~mol}$ of biodiesel and $1 \mathrm{~mol}$ of glycerol. This increased availability of glycerol (GL) has resulted in a drastic decrease in its market value. In addition, the increased price of alcohol used in biodiesel production has had a negative impact on the costeffectiveness of biodiesel production. As a result, there has been an increase in research interest on ways to increase the value of glycerol-containing wastes over the past few years.

Anaerobic fermentative biohydrogen and bioethanol production from glycerol was evaluated by Yazdani et al. [1] who demonstrated that this approach would result in a decrease in bioethanol cost by about $37 \%$ when compared to conventional bioethanol production from corn. Several types of bacteria including: Klebsiella, Citrobacter, Clostridium, Escherichia, and Enterobacter species have been studied to determine their ability to convert glycerol into biohydrogen and bioethanol, as summarized in Table 1. Previous research by Ito et al. [2] showed that Enterobacter aerogenes is a strain leading to the highest $\mathrm{H}_{2}$ and ethanol production (1.12 $\mathrm{mol} \mathrm{H}_{2}$ / mole GL and $0.96 \mathrm{~mol}$ ethanol/mole GL [2]) and was therefore selected for this study. Despite the high yield of $\mathrm{H}_{2}$ and ethanol obtained by Ito et al. [2], some challenges remain: the yield and rate of biohydrogen production must be further improved and the amount of costly compounds added to support the biological system must be minimized. As shown

\footnotetext{
* Corresponding author.

E-mail address: viviane.yargeau@mcgill.ca (V. Yargeau). 0360-3199/\$ - see front matter Copyright @ 2011, Hydrogen Energy Publications, LLC. Published by Elsevier Ltd. All rights reserved. doi:10.1016/j.ijhydene.2011.05.092
} 
in Table 1, complex media composed of salts (phosphate, nitrate, sulfate, chloride, and others) and other nutrients such as organic and non-organic acids including yeast extract and tryptone have been used. Interestingly, nitrate salt has never been used in the studies summarized in Table 1 even though Zhou et al. [3]. showed that nitrate salts support bacterial growth. The presence of oxygen in the range of $0-72.7 \mathrm{mmol}$ $\mathrm{O}_{2} / \mathrm{C}-\mathrm{mol} / \mathrm{h}$ was also shown to influence the rate of production of hydrogen by $E$. aerogenes as well as the formation of byproducts when using glucose as a substrate [4].

Accordingly, we proposed an integrated biodiesel/bioethanol/biohydrogen production scheme. In this integrated process, glycerol, the main by-product of biodiesel production, is mixed with media before being sent to a fermentation unit where glycerol is converted into ethanol, carbon dioxide, hydrogen and other minor by-products. This bioconversion would then not only produce hydrogen as clean energy to be used within the plant but would also generate ethanol that can be used as an alternative fuel or as a primary reactant in the biodiesel production process. The integrated process would improve the economical aspect of biodiesel production by using the ethanol produced as a substitute for methanol and by using or selling the hydrogen produced.

Considering the information reported in literature and with the objective of further improving the yield of hydrogen and ethanol produced from the conversion of glycerol by $E$. aerogenes, we designed an experimental plan to validate the following research hypotheses: 1 . Replacing the commonly used ammonium sulfate by ammonium nitrate will enhance cell growth and the conversion of glycerol into biohydrogen; 2 . The concentration of salts such as $\mathrm{FeSO}_{4}$ and $\mathrm{Na}_{2} \mathrm{HPO}_{4}$ can be reduced without sacrificing the biohydrogen production; 3 . The availability of some oxygen and the inoculum volume influence the biohydrogen production; and lastly, 4. Results obtained with pure glycerol apply to crude glycerol conversion. Parametric studies and Box-Behnken experimental design models were used as tools to optimize the various factors studied (salts concentration, oxygen availability and volume of inoculum).

\section{Materials and methods}

\subsection{Microorganism and inocula preparation}

E. aerogenes (ATCC 35029) was obtained from American Type Culture Collection (ATCC). The culture was started under aerobic condition in $100 \mathrm{~mL}$ of nutrient broth BD 234,000 from Becton and Dickinson Company (12 g/L) and incubated at $37{ }^{\circ} \mathrm{C}$ and $120 \mathrm{rpm}$ for $20-24 \mathrm{~h}$ to reach the stationary phase. Inocula were transferred into the nutrient broth contained in $250-\mathrm{mL}$ serum bottles using a $5 \%$ inoculum ratio. These inoculum bottles were then incubated under semi-anaerobic conditions (initial dissolved oxygen concentration of $7.0 \mathrm{mg} / \mathrm{L}$ ) at the same conditions as above until the stationary phase was reached. The initial level of dissolved oxygen was obtained by heating the broth at $50{ }^{\circ} \mathrm{C}$ for $30 \mathrm{~min}$ and then cooling it over ice to $25^{\circ} \mathrm{C}$ before capping the bottles.

\subsection{Media preparation and biohydrogen production experiments}

Otherwise specified, the glycerol-containing media was composed of the following constituents dissolved in deionised water: magnesium sulfate heptahydrate $\left(\mathrm{MgSO}_{4} .7 \mathrm{H}_{2} \mathrm{O}\right.$ : $0.2 \mathrm{~g} / \mathrm{L})$, calcium chloride $\left(\mathrm{CaCl}_{2}: 0.01 \mathrm{~g} / \mathrm{L}\right)$, glycerol $\left(\mathrm{C}_{3} \mathrm{H}_{8} \mathrm{O}_{3}\right.$ : $15 \mathrm{~g} / \mathrm{L}$ ) obtained from Sigma Aldrich, mono potassium phosphate $\left(\mathrm{KH}_{2} \mathrm{PO}_{4}: 4 \mathrm{~g} / \mathrm{L}\right)$, tetraethylenediamine disodium salts $\left(\mathrm{Na}_{2}\right.$ EDTA: $\left.0.014 \mathrm{~g} / \mathrm{L}\right)$ obtained from Fisher Scientific, and variable concentration of selected salts to be optimized: ammonium nitrate $\left(\mathrm{NH}_{4} \mathrm{NO}_{3}: 0-6 \mathrm{~g}\right)$, ferrous sulfate heptahydrate $\left(\mathrm{FeSO}_{4} \cdot 7 \mathrm{H}_{2} \mathrm{O}: 0-0.02 \mathrm{~g}\right)$ obtained from Sigma Aldrich and disodium hydrogen phosphate $\left(\mathrm{Na}_{2} \mathrm{HPO}_{4}: 0-8 \mathrm{~g}\right)$ obtained from Fisher Scientific. Pure glycerol was dissolved in deionized water in order to obtain a concentration of $40 \% \mathrm{w} / \mathrm{w}$ of glycerol. A 2-mL volume of the $40 \%$ glycerol solution was used for each experiment, corresponding to a glycerol concentration of $15 \mathrm{~g} / \mathrm{L}$, which was selected based on preliminary experiments. To reduce the amount of oxygen in the glycerolcontaining media, the solution was boiled for $20 \mathrm{~min}$, allowed to stand for $5 \mathrm{~min}$, and then cooled on ice for $5 \mathrm{~min}$ with a continuous flushing of argon in the headspace.

In order to perform the biohydrogen production experiments, inocula were transferred to glycerol-containing media $(18,50$ or $100 \mathrm{~mL})$ placed in a $125-\mathrm{mL}$ serum bottles, referred to as the experiment bottles. The transfer was done using an aseptic syringe following the Hungate technique [17]. Inocula were taken from the inoculum bottles, which were previously slightly over-pressurized with an argon/oxygen gas mixture of desired oxygen composition (0, 50 and $100 \%$ oxygen to cover the entire range of concentrations). The inoculated experiment bottles were placed in an incubator shaker at $37{ }^{\circ} \mathrm{C}$ and $120 \mathrm{rpm}$ until hydrogen production ceased. All results reported here correspond to the yield of hydrogen obtained over the entire hydrogen production period.

\subsection{Preliminary optimization of oxygen levels and of inoculum volume}

The effect of oxygen concentration during pre-cultivation of the bacteria and during inoculation on the amount of hydrogen produced was studied. The level of oxygen during pre-cultivation was varied by controlling the initial amount of oxygen available in the inoculum bottle $\left(\mathrm{O}_{2, \mathrm{~B}}\right)$. The level of oxygen during inoculation was varied by controlling the concentration of oxygen in the gas used during the transfer of the inoculum to the experiment bottles $\left(\mathrm{O}_{2, \mathrm{~T}}\right)$. To vary the amount of oxygen available in the inoculum bottles, the ratio of the volume of media added to the $125-\mathrm{mL}$ serum bottle to the bottle volume was varied, resulting in media volumes of 18, 50 and $100 \mathrm{~mL}$. The amount of oxygen in the inoculum transfer step was controlled by varying the concentration of oxygen in the gas used to over-pressurize the inoculum bottles prior to the transfer of inocula to the experiment bottles. To simultaneously study the effect of oxygen levels and the volume of inoculum on the production of hydrogen, a Box-Behnken experimental design with three independent variables, described in Table 2, was used. Each condition was performed in duplicate using the media described in section 2.2. 
Table 1 - Comparison of media composition and hydrogen and ethanol yields for the conversion of pure glycerol and crude glycerol using various types of bacteria.

\begin{tabular}{|c|c|c|c|c|c|c|c|c|c|c|c|}
\hline \multirow[t]{3}{*}{ Inoculums } & \multirow[t]{3}{*}{ Reference } & \multicolumn{2}{|c|}{$\begin{array}{l}\text { Yields } \\
\text { (mole/ } \\
\text { mole GL) }\end{array}$} & \multirow[t]{3}{*}{$\begin{array}{c}\text { Initial glycerol } \\
\text { concentration }(\mathrm{g} / \mathrm{L})\end{array}$} & \multicolumn{7}{|c|}{$\begin{array}{l}\text { Concentration } \\
(\mathrm{mg} / \mathrm{L})^{\mathrm{a}}\end{array}$} \\
\hline & & \multirow[t]{2}{*}{$\mathrm{H}_{2}$} & \multirow[t]{2}{*}{$\mathrm{ET}$} & & \multicolumn{4}{|c|}{ Organic acids } & \multicolumn{3}{|c|}{ Organic compounds } \\
\hline & & & & & $\begin{array}{l}\text { Nicotinic } \\
\text { acid }\end{array}$ & $\begin{array}{c}\mathrm{Na}_{2} \\
\text { EDTA }\end{array}$ & $\begin{array}{l}\text { p-Aminobenzoic } \\
\text { acid }\end{array}$ & $\begin{array}{l}\text { acetic } \\
\text { acid }\end{array}$ & $\begin{array}{l}\text { Yeast } \\
\text { extract }\end{array}$ & Tryptone & Biotin \\
\hline \multicolumn{12}{|l|}{ Pure glycerol } \\
\hline $\begin{array}{l}\text { Enterobacter } \\
\text { aerogenes }\end{array}$ & $\begin{array}{l}\text { [2] Ito } \\
\text { et al. (2005) }\end{array}$ & 1.05 & 1.00 & $5-25$ & 0.002 & & & & 5 & 5 & \\
\hline Escherichia coli & $\begin{array}{l}\text { [5] Murarka } \\
\text { et al. (2008) }\end{array}$ & 0.94 & 0.92 & 10 & & & & & & & \\
\hline $\begin{array}{r}\text { Enterobacter } \\
\text { aerogenes }\end{array}$ & This study & & & & & 0.004 & & & & & \\
\hline $\begin{array}{l}\text { Mixed } \\
\text { (municipal } \\
\text { waste) }\end{array}$ & $\begin{array}{l}\text { [6] Seifert } \\
\text { et al. (2009) }\end{array}$ & 0.41 & NR & 30 & & & & & 5 & & \\
\hline $\begin{array}{l}\text { Mixed } \\
\quad \text { (wheat soil) }\end{array}$ & $\begin{array}{l}\text { [7] Selembo } \\
\text { et al. (2009) }\end{array}$ & 0.28 & 0.06 & 3 & & & & & 5 & & \\
\hline $\begin{array}{l}\text { Klebsiella } \\
\quad \text { pneumoniae }\end{array}$ & $\begin{array}{l}\text { [8] Solomon } \\
\text { et al. (1994) }\end{array}$ & 0.10 & NR & 15 & & & & & & & \\
\hline $\begin{array}{l}\text { Mixed } \\
\text { (waste water) }\end{array}$ & $\begin{array}{l}\text { [9] Temudo } \\
\text { et al. (2008a) }\end{array}$ & 0.05 & 0.67 & 4.5 & & 0.05 & & & & & \\
\hline $\begin{array}{l}\text { Clostridium } \\
\text { acetobutylicum }\end{array}$ & $\begin{array}{l}\text { [10] Gonzalez- } \\
\text { Pajuelo } \\
\text { et al. (2004) }\end{array}$ & 0 & NR & 59 & & & 0.008 & 2 & 2 & & 4.E-05 \\
\hline $\begin{array}{l}\text { Clostridium } \\
\text { pasteurianum }\end{array}$ & $\begin{array}{l}\text { [11] Taconi } \\
\text { et al. (2009) }\end{array}$ & NR & 0.36 & 5 & & & & & 1 & & \\
\hline $\begin{array}{l}\text { Enterobacter } \\
\text { agglomerans }\end{array}$ & $\begin{array}{l}\text { [12] Barbirato } \\
\text { et al. (1996) }\end{array}$ & NR & 0.15 & 20 & & & & & 2 & & \\
\hline $\begin{array}{l}\text { Klebsiella } \\
\text { pneumoniae }\end{array}$ & $\begin{array}{l}\text { [12] Barbirato } \\
\text { et al. (1996) }\end{array}$ & NR & 0.03 & 20 & & & & & 2 & & \\
\hline $\begin{array}{l}\text { Clostridium } \\
\text { freundii }\end{array}$ & $\begin{array}{l}\text { [12] Barbirato } \\
\text { et al. (1996) }\end{array}$ & NR & 0.01 & 20 & & & & & 2 & & \\
\hline $\begin{array}{l}\text { Clostridium } \\
\text { butyricum }\end{array}$ & $\begin{array}{l}\text { [12] Barbirato } \\
\text { et al. (1996) }\end{array}$ & NR & 0 & 20 & & & & & & & \\
\hline $\begin{array}{l}\text { Clostridium } \\
\text { pasteurianum }\end{array}$ & [13] Biebl (2001) & NR & 0.02 & 30 & & & & & 1 & & \\
\hline $\begin{array}{l}\text { Clostridium } \\
\text { butyricum }\end{array}$ & [14] Biebl (1991) & NR & NR & 20.5 & & & & & 1 & & \\
\hline $\begin{array}{l}\text { Clostridium } \\
\text { butyricum }\end{array}$ & $\begin{array}{l}\text { [15] Saint- } \\
\text { Amans } \\
\text { et al. (1994) }\end{array}$ & NR & NR & 25 & & & 0.008 & & & & 4.E-02 \\
\hline \multicolumn{12}{|l|}{ Crude glycerol } \\
\hline $\begin{array}{l}\text { Enterobacter } \\
\text { aerogenes }\end{array}$ & $\begin{array}{l}\text { [2] Ito } \\
\text { et al. (2005) }\end{array}$ & 1.12 & 0.96 & 1.7 & 0.002 & & & & 5 & 5 & \\
\hline $\begin{array}{l}\text { Enterobacter } \\
\text { aerogenes }\end{array}$ & This study & & & & & 0.004 & & & & & \\
\hline $\begin{array}{l}\text { Mixed } \\
\text { (municipal } \\
\text { waste) }\end{array}$ & $\begin{array}{l}\text { [6] Seifert } \\
\text { et al. (2009) }\end{array}$ & 0.71 & NR & 10 & & & & & 5 & & \\
\hline $\begin{array}{l}\text { Klebsiella } \\
\text { pneumoniae }\end{array}$ & $\begin{array}{l}\text { [16] Liu and } \\
\text { Fang (2007) }\end{array}$ & 0.53 & NR & 20.4 & & & & & 3 & & \\
\hline $\begin{array}{l}\text { Mixed } \\
\qquad \text { (wheat soil) }\end{array}$ & $\begin{array}{l}\text { [7] Selembo } \\
\text { et al. (2009) }\end{array}$ & 0.31 & NR & 3 & & & & & 3 & & \\
\hline $\begin{array}{l}\text { Clostridium } \\
\text { pasteurianum }\end{array}$ & $\begin{array}{l}\text { [11] Taconi } \\
\text { et al. (2009) }\end{array}$ & NR & 0.23 & 5 & & & & & 1 & & \\
\hline $\begin{array}{l}\text { Clostridium } \\
\text { acetobutylicum }\end{array}$ & $\begin{array}{l}\text { [10] Gonzalez- } \\
\text { Pajuelo } \\
\text { et al. (2004) }\end{array}$ & NR & NR & 59 & & & 0.008 & 2 & 2 & & 4.E-05 \\
\hline
\end{tabular}

\subsection{Parametric studies for the determination of selected ranges of salts concentration}

To determine the range of concentration of the selected salts to be used in the second optimization study (described in section 2.5), the media described in section 2.2 was prepared using different concentrations of ammonium nitrate $\left(\mathrm{NH}_{4} \mathrm{NO}_{3}: 0-6 \mathrm{~g}\right)$, ferrous sulfate heptahydrate $\left(\mathrm{FeSO}_{4} \cdot 7 \mathrm{H}_{2} \mathrm{O}\right.$ : $0-0.02 \mathrm{~g})$ and of disodium hydrogen Phosphate $\left(\mathrm{Na}_{2} \mathrm{HPO}_{4}\right.$ : $0-8 \mathrm{~g})$. 


\begin{tabular}{|c|c|c|c|c|c|c|c|c|c|c|c|c|c|}
\hline \multicolumn{14}{|c|}{$\begin{array}{l}\text { Concentration } \\
(\mathrm{mg} / \mathrm{L})^{\mathrm{a}}\end{array}$} \\
\hline \multicolumn{4}{|c|}{ Phosphate } & \multicolumn{4}{|c|}{ Sulfate } & \multicolumn{6}{|c|}{ Chloride } \\
\hline $\begin{array}{c}\mathrm{K}_{2} \\
\mathrm{HPO}_{4}\end{array}$ & $\begin{array}{l}\mathrm{KH}_{2} \\
\mathrm{PO}_{4}\end{array}$ & $\begin{array}{c}\mathrm{Na}_{2} \\
\mathrm{HPO}_{4}\end{array}$ & $\begin{array}{c}\mathrm{Na} \\
\mathrm{H}_{2} \mathrm{PO}_{4}\end{array}$ & $\begin{array}{l}\left(\mathrm{NH}_{4}\right)_{2} \\
\mathrm{SO}_{4}\end{array}$ & $\begin{array}{c}\mathrm{Mg} \\
\mathrm{SO}_{4} .7 \mathrm{H}_{2} \mathrm{O}\end{array}$ & $\begin{array}{l}\mathrm{FeSO}_{4} \\
7 \mathrm{H}_{2} \mathrm{O}\end{array}$ & $\begin{array}{c}\mathrm{ZnSO}_{4} \\
7 \mathrm{H}_{2} \mathrm{O}\end{array}$ & $\begin{array}{l}\mathrm{CaCl}_{2} . \\
2 \mathrm{H}_{2} \mathrm{O}\end{array}$ & $\mathrm{NiCl}_{2}$ & $\mathrm{NH}_{4} \mathrm{CL}$ & $\mathrm{MgCl}_{2} \cdot 6 \mathrm{H}_{2} \mathrm{O}$ & $\mathrm{CaCl}_{2} \cdot 2 \mathrm{H}_{2} \mathrm{O}$ & $\mathrm{CoCl}_{2} \cdot 6 \mathrm{H}_{2} \mathrm{O}$ \\
\hline \multirow[t]{3}{*}{7} & 5.5 & & & 1 & 0.3 & & & 0.21 & 2.E-05 & & & & \\
\hline & & 0.19 & & & & 0.422 & & & & 0.51 & 0.11 & 0.008 & \\
\hline & & 12.2 & & & 0.2 & 0.006 & & & & & & & \\
\hline 0.25 & 0.25 & & & & 0.3 & & & & & 0.5 & & 0.05 & 0.02 \\
\hline \multirow[t]{3}{*}{4.58} & 2.45 & & & 2 & 0.2 & 0.005 & & & & 13.8 & & 1.5 & \\
\hline & & 1.38 & & & & & & & & 5.35 & 0.26 & 2.9 & \\
\hline & 0.78 & & & & & 0.003 & 0 & & & 1.34 & 0.12 & $6 . E-04$ & $6 . E-04$ \\
\hline 0.5 & 0.5 & & & & 0.2 & 0.038 & & & & 1.5 & & & 0.01 \\
\hline 0.5 & 0.5 & & & 3 & 0.2 & 0.005 & & & & & & 0.02 & \\
\hline 5 & 3 & & & 2 & 0.4 & & & & & & & 0.1 & 0.004 \\
\hline 5 & 3 & & & 2 & 0.4 & & & & & & & 0.1 & 0.004 \\
\hline 5 & 3 & & & 2 & 0.4 & & & & & & & 0.1 & 0.004 \\
\hline 3.4 & 1.3 & & & 2 & 0.2 & & & & & & & 0.02 & \\
\hline 0.5 & 0.5 & & & 3 & 0.2 & 0.005 & & & & & & 0.02 & \\
\hline 3.4 & 1.3 & & & 2 & 0.2 & 0.005 & & & & & & 0.02 & \\
\hline 0.55 & 0.55 & & & & 0.2 & 0.010 & & & & 1.65 & & & 0.01 \\
\hline \multirow[t]{2}{*}{7} & 5.5 & & & 1 & 0.3 & & & & 2.E-05 & & & 0.02 & \\
\hline & & 12.2 & & & 0.2 & 0.006 & & & & & & & \\
\hline 0.25 & 0.25 & & & & 0.3 & & & & & 0.5 & & 0.05 & 0.02 \\
\hline \multirow[t]{2}{*}{3.4} & 1.3 & & & 2 & 0.2 & 0.005 & & & & & & & \\
\hline & & 4.58 & 2.45 & 2 & 0.2 & 0.005 & & & & 13.8 & & 1.5 & \\
\hline 0.5 & 0.5 & & & 2 & 0.2 & 0.005 & & & & & & 0.02 & \\
\hline 0.5 & 0.5 & & & & 0.2 & 0.038 & & & & 1.5 & & & \\
\hline
\end{tabular}

\subsection{Optimization of oxygen concentration, volume of} inoculum and selected salts concentration

For the optimization of the concentration of the selected salts, the volume of the inocula and the effect of oxygen concentration, a Box-Behnken experimental design with five independent variables, described in Table 3, were used. Each condition was performed in duplicate.

For predicting the optimal conditions, the Software SAS 9.2 obtained from the company SAS was used to fit a quadratic equation to correlate relationship between variables and response (i.e. volume of hydrogen). A complete description of 
Table 2 - Factors and levels used in the $3^{3}$ Box-Behnken experimental design.

\begin{tabular}{lcccc} 
Factors & Label & $\begin{array}{c}\text { Low } \\
\text { level }\end{array}$ & $\begin{array}{c}\text { Center } \\
\text { point }\end{array}$ & $\begin{array}{r}\text { High } \\
\text { level }\end{array}$ \\
\hline $\begin{array}{l}\text { Initial } \mathrm{O}_{2} \text { concentration in } \\
\text { the inoculum bottle } \\
\text { expressed as a volume }\end{array}$ & $\mathrm{O}_{2, \mathrm{~B}}$ & 0.15 & 0.4 & 0.8 \\
ratio, media/bottle & & & & \\
$\begin{array}{l}\text { Volume of inoculum (mL) } \\
\mathrm{O}_{2} \text { level in the gas used to } \\
\text { transfer inoculum (\%) }\end{array}$ & $\mathrm{V}_{\mathrm{I}}$ & 5.6 & 7.5 & 9.4 \\
\hline
\end{tabular}

\begin{tabular}{lllll}
$\begin{array}{l}\text { Table } \mathbf{3} \text { - Factors and levels used in the } \mathbf{3}^{\mathbf{5}} \text { Box-Behnken } \\
\text { experimental design. }\end{array}$ & Label & $\begin{array}{c}\text { Low } \\
\text { level }\end{array}$ & $\begin{array}{c}\text { Center } \\
\text { point }\end{array}$ & $\begin{array}{c}\text { High } \\
\text { level }\end{array}$ \\
\hline Factors & & 2.5 & 5 & 7.5 \\
\hline $\begin{array}{l}\mathrm{O}_{2} \text { level in the gas used } \\
\text { to transfer inoculum } \\
(\%)\end{array}$ & $\mathrm{O}_{2, \mathrm{~T}}$ & & & \\
$\begin{array}{l}\text { Volume of inoculum } \\
(\mathrm{mL})\end{array}$ & $\mathrm{V}_{\mathrm{I}}$ & 5.6 & 7.5 & 9.4 \\
$\begin{array}{l}\mathrm{Na}_{2} \mathrm{HPO}_{4}(\mathrm{~g} / \mathrm{L}) \\
\mathrm{NH}_{4} \mathrm{NO}_{3}(\mathrm{~g} / \mathrm{L})\end{array}$ & $\mathrm{PO}_{4}$ & 4 & 6 & 8 \\
$\mathrm{FeSO}_{4}(\mathrm{~g} / \mathrm{L})$ & $\mathrm{NO}_{3}$ & 1.5 & 2.0 & 2.5 \\
\hline $\mathrm{SO}_{4}$ & 0.00375 & 0.005 & 0.00625 \\
\hline
\end{tabular}

the process behaviour requires a quadratic or cubic model [18]. The quadratic correlation was estimated as the following equation:

$\mathrm{Y}=b_{0}+\sum b_{\mathrm{i}} \mathrm{X}_{\mathrm{i}}+\sum b_{\mathrm{ii}} \mathrm{X}_{\mathrm{i}}^{2}+\sum b_{\mathrm{ij}} \mathrm{X}_{\mathrm{i}} \mathrm{X}_{\mathrm{j}}$

where $Y$ is the response; $X_{i}$, and $X_{j}$ are the uncoded independent variables, $b_{0}, b_{i}, b_{i i}$, and $b_{i j}$ are the intercept, linear, quadratic and interaction constant coefficients, respectively.

\subsection{Validation of results using crude glycerol}

The optimal conditions determined in the previous sections were used to evaluate the potential conversion of crude glycerol under these conditions and to compare with the results obtained using pure glycerol. Crude glycerol was first filtered (vacuum filtration using filter paper P8 and P4 purchased from Fisher Scientific) and then dissolved in deionised water in order to obtain stock solutions with concentrations of 20,40 , and $60 \% \mathrm{w} / \mathrm{w}$ of crude glycerol. Similarly, pure glycerol was dissolved in deionized water in order to obtain stock solutions of concentrations of 20, 40,60 and $80 \% \mathrm{w} / \mathrm{w}$ of pure glycerol. A 2-mL volume of each concentration was used for experiments which tested the effect of glycerol concentration on hydrogen production, resulting in crude glycerol concentrations of 12,18 , and $28 \mathrm{~g} / \mathrm{L}$ and pure glycerol concentrations of 7, 15, 23 and $34 \mathrm{~g} / \mathrm{L}$.

\subsection{Analytical methods}

The volume of biogas produced was measured using a hypodermic syringe every $24 \mathrm{~h}$. Samples of the biogas were analyzed by gas chromatography to determine the concentration of hydrogen. A Hewlett Packard GC model 5890 equipped with a $6^{\prime}$ molecular sieve column $8 \mathrm{~A}$ maintained at a temperature of $80^{\circ} \mathrm{C}$ was used. Argon was used as the carrier gas at a flow rate of $3.0 \mathrm{~mL} / \mathrm{min}$ and a thermal conductivity detector (TCD) was used. Samples of liquid were collected to monitor cell growth and to characterize the final composition of the liquid when biohydrogen production ceased. Cell growth was monitored by optical density measurements performed at $600 \mathrm{~nm}$ using an Evolution $300 \mathrm{UV}$-visible Spectrometer. In order to determine the residual solution composition, the liquid samples were centrifuged at 10,000 rpm for $10 \mathrm{~min}$. The supernatant was then mixed with silver powder and centrifuged again at $5000 \mathrm{rpm}$ in order to remove chloride ions. The supernatant was collected for liquid chromatography, ion chromatography and inductively coupled mass spectrometry (ICP-MS) analysis. A Hewlett Packard 1050 High-Performance Liquid Chromatograph (HPLC) equipped with a Rezex ROA Organic Acid $\mathrm{H}^{+} 8 \%$ $150 \times 7.80 \mathrm{~mm}$ column and a refractive index detector (RI) HP1047A was used to measure the concentration of glycerol, 1,3-propanediol, pyruvate, lactate, acetate, formate, and

\begin{tabular}{|c|c|c|}
\hline $\mathrm{O}_{2, \mathrm{~T}}=0 \%$ & $\mathrm{O}_{2, \mathrm{~T}}=50 \%$ & $\mathrm{O}_{2, \mathrm{~T}}=100 \%$ \\
\hline
\end{tabular}
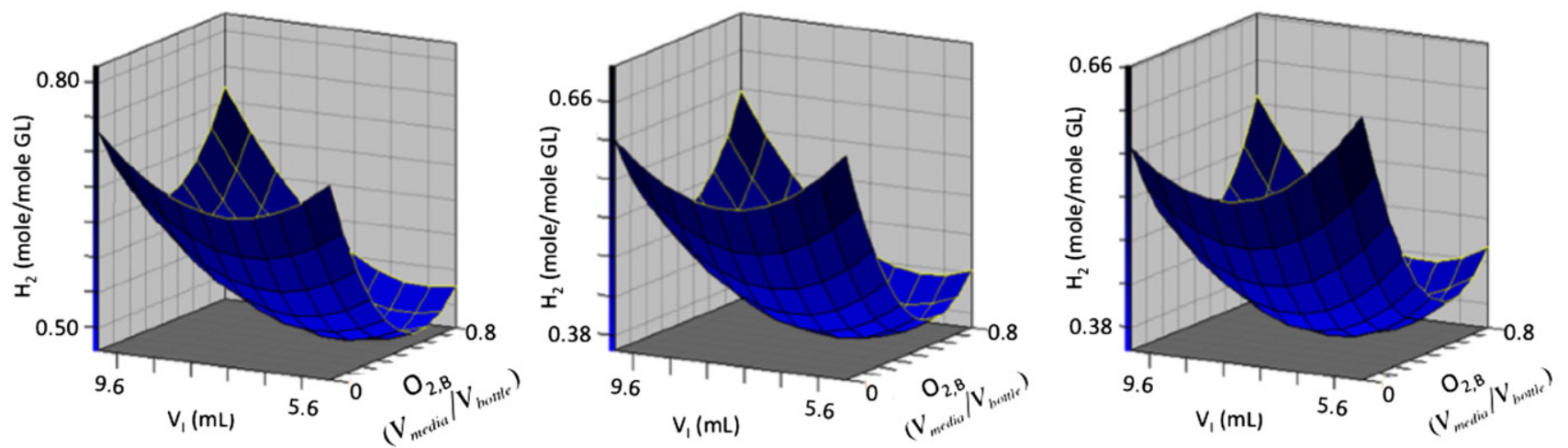

Fig. 1 - Three-dimensional response plots for the hydrogen production at various levels of inoculum volumes and levels of oxygen in the inoculum transfer and inoculum bottle. 

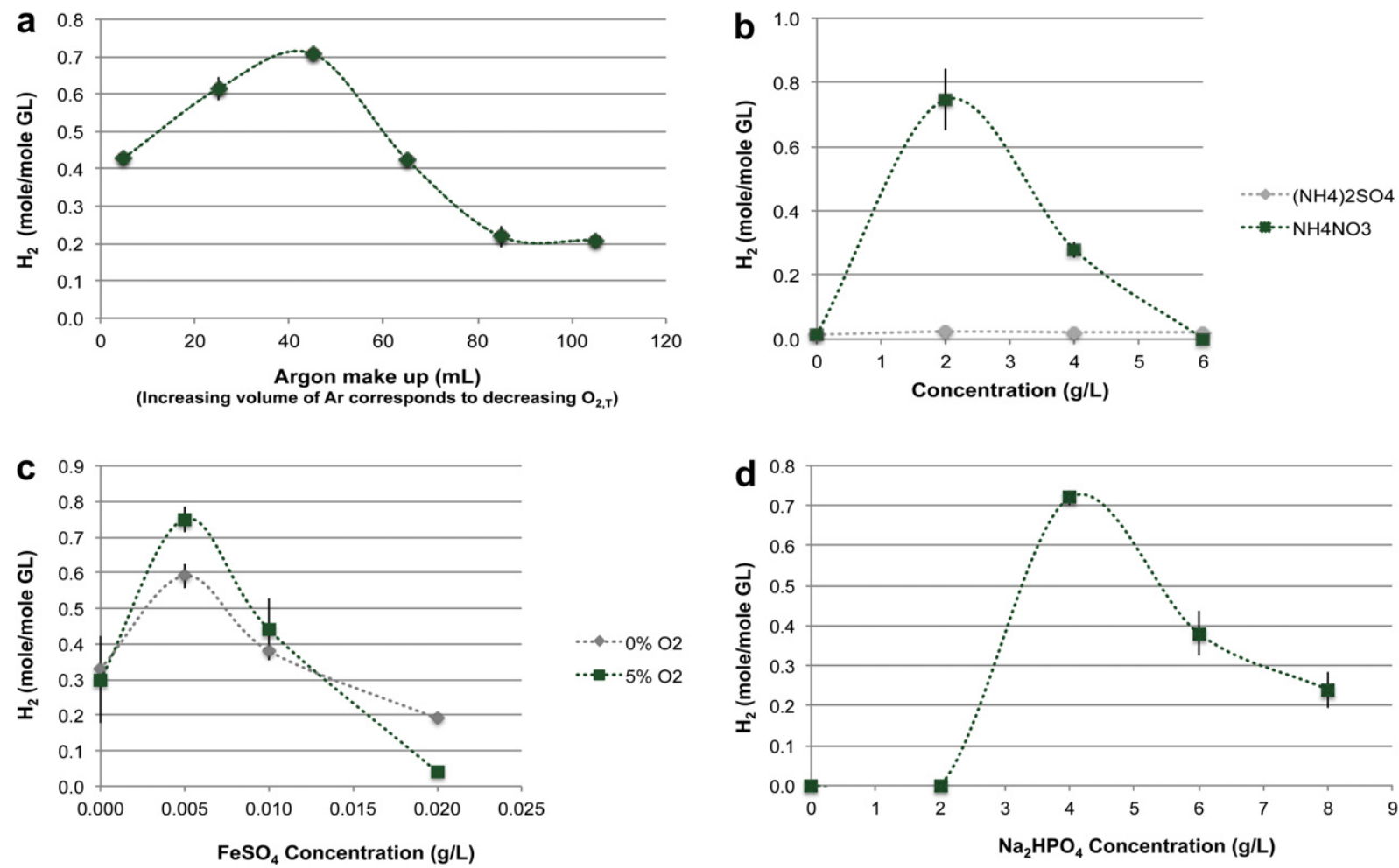

Fig. 2 - (a) $\mathrm{H}_{2}$ production as a function of the cumulative volume of argon gas injected in the inoculum bottle prior to transfer of inoculums; (b) Comparison of hydrogen production using $0 \mathrm{~g} / \mathrm{L}$ to $6 \mathrm{~g} / \mathrm{L}$ of $\left(\mathrm{NH}_{4}\right)_{2} \mathrm{SO}_{4}(\diamond)$ and $\mathrm{NH}_{4} \mathrm{NO}_{3}$ ( $(\square)$; (c) Comparison of hydrogen production using $0 \mathrm{~g} / \mathrm{L}$ to $0.02 \mathrm{~g} / \mathrm{L}$ of $\mathrm{FeSO}_{4}$ for two concentrations of oxygen in the inoculum transfer: $5 \% \mathrm{O}_{2}$ in Argon gas ( $\square$ ) and pure Argon ( $\diamond)$; (d) Hydrogen production using concentrations of $\mathrm{Na}_{2} \mathrm{HPO}_{4}$ in the $0 \mathrm{~g} / \mathrm{L}$ to $8 \mathrm{~g} / \mathrm{L}$ range (Error bar: standard deviation of three replicates).

ethanol. The mobile phase was $0.035 \mathrm{M} \mathrm{H}_{2} \mathrm{SO}_{4}$ at a flow rate of $0.8 \mathrm{~mL} / \mathrm{min}$ and a run time of $12 \mathrm{~min}$. The column temperature was $65^{\circ} \mathrm{C}$ and the temperature of detector was $50{ }^{\circ} \mathrm{C}$. Organic anions, namely formate and acetate, and inorganic ions such as nitrite, nitrate, sulfate, and phosphate were monitored using ion chromatography (IC). An ion chromatograph (Metrohm model 820 IC) equipped with a Metrosep A supp7 250/ $4.0 \mathrm{~mm}-5 \mu \mathrm{m}$ column maintained at $45^{\circ} \mathrm{C}$ and a conductivity detector was used with $3 \mathrm{mM} \mathrm{Na}_{2} \mathrm{CO}_{3}$ as a mobile phase.

\section{Results and discussion}

\subsection{Preliminary optimization of level of oxygen in} inoculum and of inoculum volume

Fig. 1 presents the results of the $3^{3}$ Box-Behnken design and Response Surface Methodology (RSM) used to optimize three independent variables: the level of oxygen in the inoculum

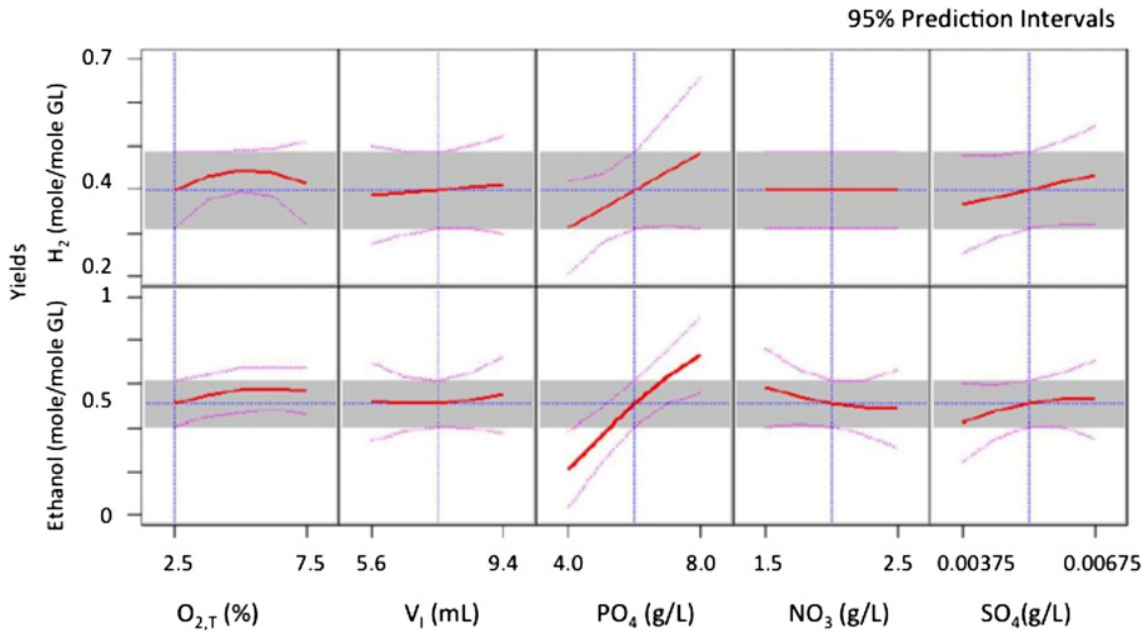

Fig. 3 - 95\% Prediction Intervals for the five factors studied (\% oxygen $\left(\mathrm{O}_{2, \mathrm{~T}}\right)$, inoculum volume $\left(\mathrm{V}_{\mathrm{I}}\right)$, concentration of $\mathrm{Na}_{2} \mathrm{HPO}_{4}$ $\left(\mathrm{PO}_{4}\right), \mathrm{NH}_{4} \mathrm{NO}_{3}\left(\mathrm{NO}_{3}\right)$ and $\left.\mathrm{FeSO}_{4}\left(\mathrm{SO}_{4}\right)\right)$. 


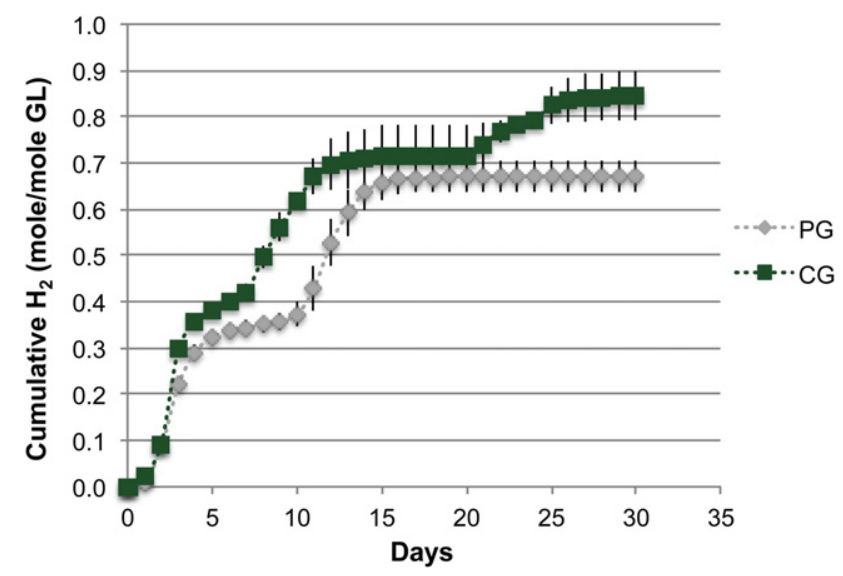

Fig. 4 - Comparison of the cumulative hydrogen production (mole/mole GL) using pure glycerol $(\diamond)$ and crude glycerol ( $\square$ ) at the same glycerol concentration of $15 \mathrm{~g} / \mathrm{L}$ (Error bar: standard deviation of three replicates).

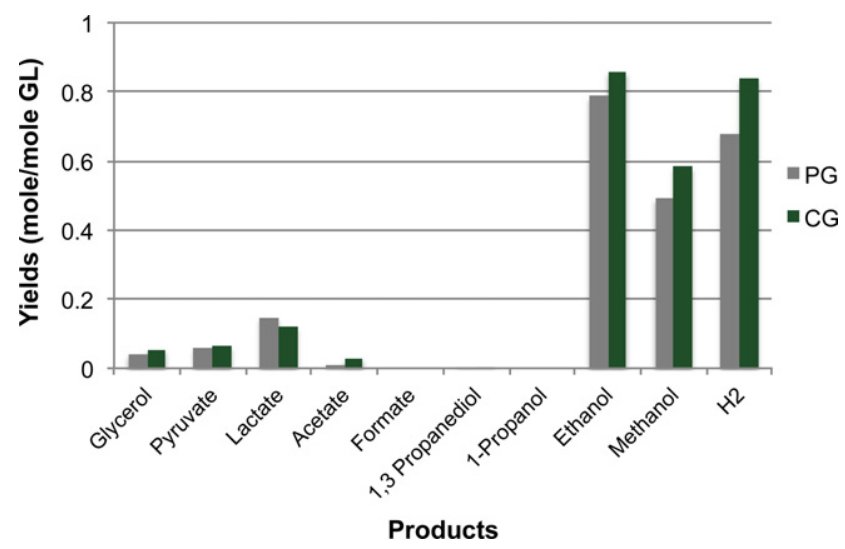

Fig. 5 - Comparison of metabolites produced using pure glycerol and crude glycerol obtained from biodiesel process at the same glycerol concentration, $15 \mathrm{~g} / \mathrm{L}$.

bottles $\left(\mathrm{O}_{2, \mathrm{~B}}\right)$, the oxygen level used during the inoculum transfer $\left(\mathrm{O}_{2, \mathrm{~T}}\right)$, and the volume of inoculum $\left(\mathrm{V}_{\mathrm{I}}\right)$. A comparison of the three graphs for oxygen concentration at 0,50 , and 100 percent indicated that the highest amount of hydrogen was obtained at $0 \%$ oxygen in the transfer step $\left(\mathrm{O}_{2, \mathrm{~T}}\right)$. Looking at the first graph on the left, based on a $\mathrm{O}_{2, \mathrm{~T}}$ of $0 \%$, the largest

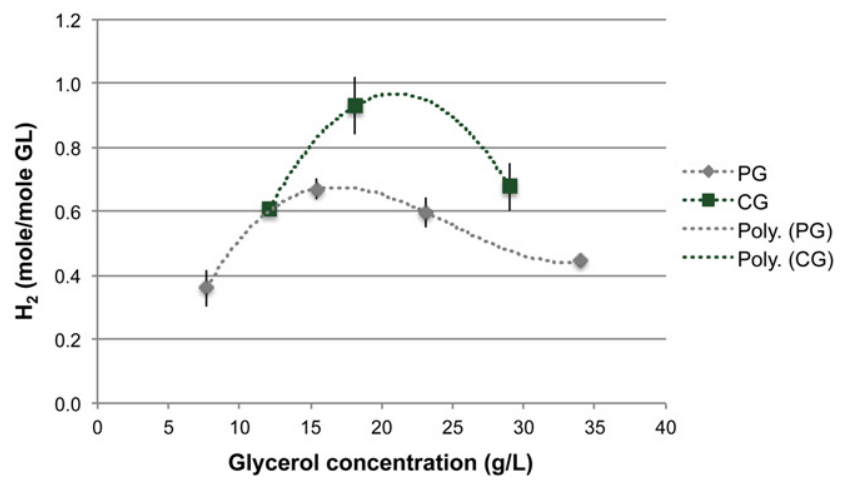

Fig. 6 - Comparison of the hydrogen production using various concentrations of pure glycerol (PG) and crude glycerol (CG) obtained from biodiesel process.

volume of inoculum resulted in better results and the highest amount of oxygen in the inoculum bottle (ratio of 0 ) enhanced the hydrogen production.

Considering that the oxygen concentration range studied in the transfer step was large $(0-100 \%)$ it was important to investigate whether the previous results predict an optimal production at strict anaerobic conditions or if semi-anaerobic conditions would suffice or may be better. To validate this hypothesis, repeated injections of oxygen-free argon gas into the inoculum bottle were used for multiple inoculum transfers from the same inoculum bottle, corresponding to a decreasing $\mathrm{O}_{2, \mathrm{~T}}(20 \%$ and below as opposed to the range of $0-100 \%$ as presented in Fig. 1). Fig. 2a presents the amount of hydrogen produced in the experiment bottles inoculated from this inoculum bottle as a function of the cumulative amount of oxygen-free argon gas used in the transfer of inocula. The trend observed clearly indicates that the initial decrease in oxygen concentration was beneficial but that past a certain level, it had a detrimental effect. This indicates that a low concentration of oxygen is required but that oxygen-free conditions are not optimal. As a result, the concentration range used in the optimization study was $2.5-7.5 \% \mathrm{O}_{2}$ in the transfer step $\left(\mathrm{O}_{2, \mathrm{~T}}\right)$.

\subsection{Determination of ranges of salts concentration for the optimization study}

\subsubsection{Ammonium salt}

Many researchers have used $\left(\mathrm{NH}_{4}\right)_{2} \mathrm{SO}_{4}$ in the media used for biohydrogen production along with many other salts and

\begin{tabular}{|c|c|c|c|c|c|c|c|c|c|c|c|c|c|}
\hline Additives & $\mathrm{Na}_{2} \mathrm{HPO}_{4}$ & $\mathrm{~K}_{2} \mathrm{HPO}_{4}$ & $\mathrm{KH}_{2} \mathrm{PO}_{4}$ & $\begin{array}{l}\left(\mathrm{NH}_{4}\right)_{2} \\
\mathrm{SO}_{4}\end{array}$ & $\mathrm{NH}_{4} \mathrm{NO}_{3}$ & $\mathrm{NH}_{4} \mathrm{Cl}$ & $\mathrm{K}_{2} \mathrm{SO}_{4}$ & $\begin{array}{l}\mathrm{FeSO}_{4} . \\
7 \mathrm{H}_{2} \mathrm{O}\end{array}$ & $\begin{array}{l}\mathrm{MgSO}_{4} \\
7 \mathrm{H}_{2} \mathrm{O}\end{array}$ & $\begin{array}{c}\mathrm{MgCl}_{2} . \\
6 \mathrm{H}_{2} \mathrm{O}\end{array}$ & $\begin{array}{l}\mathrm{CaCl}_{2} . \\
2 \mathrm{H}_{2} \mathrm{O}\end{array}$ & $\mathrm{NaCl}$ & $\mathrm{Na}_{2} \mathrm{EDTA}$ \\
\hline$\$ C A D / \mathrm{Kg}^{\mathrm{a}}$ & $\$ 65$ & $\$ 160$ & $\$ 161$ & $\$ 79$ & $\$ 64$ & $\$ 83$ & $\$ 95$ & $\$ 149$ & $\$ 100$ & $\$ 242$ & $\$ 103$ & $\$ 43$ & $\$ 140$ \\
\hline $\begin{array}{l}\text { Ito et al. (2005) } \\
\text { (g/L used) }\end{array}$ & & 7 & 5.5 & 1 & & & & & 0.25 & & 0.02 & & \\
\hline $\begin{array}{l}\text { This study } \\
\text { (g/L used) }\end{array}$ & 12.2 & & & & 1.5 & & & 0.01 & 0.2 & & & & 0.004 \\
\hline
\end{tabular}


nutrients as shown in Table 1. The objective of this parametric study was to identify the range of concentrations to use in the optimization study and to evaluate the possible replacement of $\left(\mathrm{NH}_{4}\right)_{2} \mathrm{SO}_{4}$ by $\mathrm{NH}_{4} \mathrm{NO}_{3}$. Fig. $2 \mathrm{~b}$ presents the results obtained using the same concentrations of both salts. The data clearly indicate that the use of $\mathrm{NH}_{4} \mathrm{NO}_{3}$ results in a higher hydrogen production when compared to the use of the same concentration of $\left(\mathrm{NH}_{4}\right)_{2} \mathrm{SO}_{4}$ and that an optimal point seems to be approximately $2 \mathrm{~g} / \mathrm{L}$. Based on these results, $\mathrm{NH}_{4} \mathrm{NO}_{3}$ was selected for the optimization study and the range of concentrations to study was set to $1.5-2.5 \mathrm{~g} / \mathrm{L}$.

\subsubsection{Iron sulfate}

Results obtained in the range of $0 \mathrm{~g} / \mathrm{L}$ to $0.02 \mathrm{~g} / \mathrm{L}$ of $\mathrm{FeSO}_{4}$ indicate that the salt has a significant non-linear effect on biohydrogen production. Fig. 2c, presents the results obtained both in the absence of oxygen and in the presence of some oxygen (5\%) in the inoculum transfer step and indicates that an optimal concentration of $\mathrm{FeSO}_{4}$ is close to $0.005 \mathrm{~g} / \mathrm{L}$ in both cases. These results also indicate a possible interaction between the two factors. From these results, the range concentration of $\mathrm{FeSO}_{4}$ for the optimization study was set to $0.00375-0.00625 \mathrm{~g} / \mathrm{L}$.

\subsubsection{Sodium phosphate}

Results presented in Fig. 2d indicated that $\mathrm{Na}_{2} \mathrm{HPO}_{4}$ is required to obtain a measurable amount of hydrogen and confirmed the existence of an optimal concentration within the range studied. Based on these results, a range of $4.0-8.0 \mathrm{~g} / \mathrm{L}$ was selected for the optimization study.

\subsection{Optimization of oxygen concentration, volume of inoculum and selected salts concentration}

The five independent variables studied, consisting of \% oxygen in the inoculum transfer $\left(\mathrm{O}_{2, \mathrm{~T}}\right)$, inoculum volume $\left(\mathrm{V}_{\mathrm{I}}\right)$, amount of $\mathrm{Na}_{2} \mathrm{HPO}_{4}\left(\mathrm{PO}_{4}\right), \mathrm{NH}_{4} \mathrm{NO}_{3}\left(\mathrm{NO}_{3}\right)$, and $\mathrm{FeSO}_{4}\left(\mathrm{SO}_{4}\right)$, were optimized for the yield of hydrogen and ethanol using a Box Behnken design and Response Surface Methodology (RSM). Fig. 3, presenting the 95\% prediction profile for each variable (grey area), summarizes the analysis of the 46 runs of the experimental design (performed in duplicate). Note that for each variable the middle line represents the average predicted values while the lower and upper lines represent the limit of range of the predicted values. The lower yield values reported here, as compared to some values on Fig. 2, are explained by the fact that results for each variable are those obtained at the middle values of the range studied for each of the other variables, which don't correspond to the optimal conditions.

These results indicate that the percent of oxygen, $\mathrm{Na}_{2} \mathrm{HPO}_{4}$ and $\mathrm{FeSO}_{4}$ significantly affect the amount of hydrogen and ethanol produced. The volume of inoculum has a slight influence and the concentration of $\mathrm{NH}_{4} \mathrm{NO}_{3}$ has a negligible effect on biohydrogen production, but a significant effect on ethanol production. For the most significant factor, the higher level of $\mathrm{Na}_{2} \mathrm{HPO}_{4}$, most probably acting as a buffer and balancing $\mathrm{pH}$ as acidic metabolites form, helped support growth and enhanced the production of hydrogen and ethanol. A higher concentration of $\mathrm{FeSO}_{4}$ also enhanced the production of hydrogen and ethanol by providing iron and oxygen to the cells. A small amount of oxygen in the inoculum transfer step significantly enhanced the hydrogen and ethanol production while slightly more inhibited it. This confirms the trend observed in Fig. 2a indicating that complete anaerobic conditions are not desirable. We hypothesize that $E$. aerogenes uses this small amount of oxygen while adjusting to the new media in order to proliferate in the new environment. This hypothesis is supported by a study conducted by Tanisho et al. [19] reporting that E. aerogenes quickly respond to dissolved oxygen. E. aerogenes consume externally-supplied, gaseous oxygen before using oxygen from the decomposable salts $\left(\mathrm{NO}_{3}{ }^{-} \mathrm{SO}_{4}{ }^{2-}\right.$, and $\left.\mathrm{PO}_{4}{ }^{3-}\right)$. This is also supported by results presented in Fig. $2 \mathrm{~b}$ which show that E. aerogenes utilize $\mathrm{NO}_{3}{ }^{-}$ more readily than $\mathrm{SO}_{4}{ }^{2-}$, when provided as ammonium salts. These results also agree with a study performed by Zhou et al. [3] which showed that E. aerogenes utilize $\mathrm{NO}_{3}{ }^{-}$obtained from $\mathrm{NH}_{4} \mathrm{NO}_{3}$ (or $\mathrm{NaNO}_{3}$ ) anaerobically more readily than aerobically. In addition, they found that $\mathrm{NH}_{4}{ }^{+}$and $\mathrm{NO}_{3}{ }^{-}$consumption are heavily supported by metal ions such as $\mathrm{Fe}^{2+}$. This was also observed in this study as presented in Fig. $2 \mathrm{c}$ which indicates that without $\mathrm{Fe}^{2+}$, obtained from $\mathrm{FeSO}_{4}$, low hydrogen production is observed.

Results from the optimization clearly showed that a small amount of oxygen is required in the pre-culture in order to increase the hydrogen and ethanol production by E. aerogenes. The optimized conditions for pure glycerol (PG) were determined using the Box-Beknhen design and are: $8 \mathrm{~g} / \mathrm{L} \mathrm{Na}_{2} \mathrm{HPO}_{4}$, $0.00625 \mathrm{~g} / \mathrm{L} \mathrm{FeSO}_{4}, 1.5 \mathrm{~g} / \mathrm{L} \mathrm{NH}_{4} \mathrm{NO}_{3}$, an inoculum volume of $9.4 \mathrm{~mL}(18 \% \mathrm{vol}$ inoculum) and $7.5 \%$ of oxygen in the gas used in the inoculum transfer step. The maximum yields obtained with the conditions tested ( $15 \mathrm{~g} / \mathrm{L}$ of glycerol) were $0.78 \mathrm{~mol}$ ethanol/mol GL and $0.67 \mathrm{~mol} \mathrm{H}_{2} / \mathrm{mol} \mathrm{GL}$ and can be compared with results from Ito et al. [2] who report values of $0.67 \mathrm{~mol}$ ethanol/mol GL and $0.71 \mathrm{~mol} \mathrm{H}_{2} / \mathrm{mol}$ when using $10 \mathrm{~g} / \mathrm{L}$ glycerol.

\begin{tabular}{|c|c|c|c|c|c|c|c|c|c|c|c|c|c|}
\hline $\begin{array}{c}\mathrm{Na}_{2} \mathrm{MoO}_{4} \text {. } \\
2 \mathrm{H}_{2} \mathrm{O}\end{array}$ & $\mathrm{Na}_{2} \mathrm{SeO}_{3}$ & $\mathrm{NiCl}_{2}$ & Nicotinic a. & MOPS & Tricine & $\begin{array}{c}\text { Yeast } \\
\text { Extract }\end{array}$ & Tryptone & $\mathrm{MnCl}_{2} \cdot 4 \mathrm{H}_{2} \mathrm{O}$ & $\mathrm{CuCl}_{2} \cdot 2 \mathrm{H}_{2} \mathrm{O}$ & $\mathrm{H}_{3} \mathrm{BO}_{3}$ & $\mathrm{AlK}\left(\mathrm{SO}_{4}\right)_{2}$ & $\mathrm{Na}_{2}$ EDTA & $\begin{array}{c}\text { Cost of } \\
\text { additives } \\
\text { (CAD \$/L } \\
\text { of media) }\end{array}$ \\
\hline$\$ 276$ & $\$ 742$ & $\$ 638$ & $\$ 74$ & $\$ 1190$ & $\$ 480$ & $\$ 61$ & $\$ 247$ & $\$ 184$ & $\$ 371$ & $\$ 51$ & $\$ 496$ & $\$ 140$ & \\
\hline 0.12 & 0.0002 & 0.00002 & 0.002 & & & 5 & 5 & 0.5 & 0.001 & 0.1 & 0.01 & 0.5 & $\$ 3.85$ \\
\hline & & & & & & & & & & & & & $\$ 0.91$ \\
\hline
\end{tabular}




\subsection{Comparison of yields using crude glycerol}

A comparison between the results obtained with pure glycerol (PG) and crude glycerol (CG) using the optimized salts concentrations and oxygen concentrations was performed. The results are shown in Fig. 4 and indicate that over the 30 days of the experiment, two production phases occurred. Overall, CG (18 g/L) yielded hydrogen at $0.85 \mathrm{~mol} / \mathrm{mol} \mathrm{GL}$, which is higher than the value obtained with PG $(15 \mathrm{~g} / \mathrm{L})$, $0.67 \mathrm{~mol} / \mathrm{mol}$ GL. Similar initial lag phases $(\lambda$, measured in days) were obtained but a longer second lag-phase time was observed for pure glycerol. Using the modified Gompertz equation [20] to model the hydrogen production, the second lag-phase was 7 and 9 days for CG and PG, respectively. There was also a significant difference in the rates of production $\left(R_{m}\right.$, measured in mole/mole GL/day). Again using the Gompertz equation, it was determined that CG had primary and secondary production rates of 0.2037 and 0.0550 respectively, while PG had rates of 0.1334 and 0.0112 , respectively. The CG rates were therefore 1.5 and 5 times higher than PG rates. The shorter lag-phase and faster reaction rate might be explained by the presence of other organic compounds such as free fatty acids and non-glycerol organic matter which may support the growth of bacteria during the second lag phase. Similarly, Seifert et al. [14] obtained a higher biohydrogen production using crude glycerol from biodiesel production as opposed to Ito et al. [2] who reported that residual compounds in crude glycerol inhibited microbial production of hydrogen. The addition of yeast extract and tryptone by Ito et al. may have resulted in an over-supply of organic compounds in the system, as suggested by Thompson et al. [21], and may explain the different results. Analysis of the liquid phase for the various products resulting from the glycerol conversion: pyruvate, lactate, acetate, ethanol, methanol and $\mathrm{H}_{2}$ (Fig. 5) indicate similar production levels and provide no insight on explaining the increased yields obtained using crude glycerol. However, again it indicates that there is a significant production of ethanol which is worth investigating further.

\subsubsection{Effects of glycerol concentration}

The effect of glycerol concentration on the yield of hydrogen was also studied for both pure and crude glycerol. The results reported in Fig. 6 indicate that concentrations above $12 \mathrm{~g} / \mathrm{L}$ crude glycerol gives better results and that different optimal concentrations exist for each type of glycerol; approximately $17 \mathrm{~g} / \mathrm{L}$ for pure glycerol and $21 \mathrm{~g} / \mathrm{L}$ for crude glycerol (no measured values available at these concentrations). Using the Gompertz equation to model the hydrogen production from crude glycerol presented in Fig. 6, the predicted maximum hydrogen yield would be $0.95 \mathrm{~mol} / \mathrm{mol}$ GL at a glycerol concentration of $21 \mathrm{~g} / \mathrm{L}$. Fabiano and Perego [20] observed a similar effect of glycerol concentration on the amount of hydrogen produced although Ito et al. [2] reported a decrease in hydrogen production with an increase glycerol concentration. These results support the hypothesis that other compounds present in crude glycerol better supported the microbial system and might have contributed to the hydrogen production. However, an excess of these organic compounds has a sharper inhibition effect on biohydrogen production than glycerol alone as revealed by the steeper decreasing slope past the optimal point (Fig. 6).

Importantly, the optimization performed here was conducted using a less complex media that the one used in most previous research. By comparison with Ito et al. [2] who reported the highest yield for pure and crude glycerol converted by E. aerogenes (Table 1), the simplified media composition used in this study resulted in an approximate media cost saving in \$CAD/L of $76 \%$ without sacrificing the hydrogen and ethanol yields. The data used to estimate these costs are summarized in Table 4.

\section{Concluding remarks}

In this study, the concentration of three salts and the volume of inoculum were optimized and the importance of maintaining some oxygen in the pre-culture and inoculum transfer, rather than the conventionally used anaerobic conditions was demonstrated, in order to maximize the yield of hydrogen. We were successful in increasing the hydrogen yield from the previously reported maximum value of 0.71 [2] to a predicted value of $0.95 \mathrm{~mol} \mathrm{H}_{2} / \mathrm{mol} \mathrm{GL}$ and 0.79 ethanol/mol GL for a glycerol concentration of $21 \mathrm{~g} / \mathrm{L}$ in crude glycerol, while at the same time decreasing the cost of salts addition by $76 \%$. In order to continue to improve the viability of biohydrogen processes, the rate of hydrogen production must be further increased. Other possible ways of increasing the rate of hydrogen production include optimizing the concentration of other salts and nutrients such as yeast extract, tryptone, or peptone, which have been customarily used by many researchers as summarized in Table 1 as well as optimizing the cell density. Another alternative would be to improve the hydrogen-capability of the strain used in such systems.

\section{Acknowledgements}

This work was partly funded by the Thailand Institute of Scientific and Technological Research, the Natural Sciences and Engineering Research Council of Canada (NSERC) and the Fonds Québécois pour la Recherche en Nature et Technologies (FQRNT). Thanks to Andrew Golsztajn and Ranjan Roy for their analytical support.

\section{R E F E R E N C E S}

[1] Yazdani SS, Gonzalez R. Anaerobic fermentation of glycerol: a path to economic viability for the biofuels industry. Curr Opin Biotech 2007;18:213-9.

[2] Ito T, Nakashimada Y, Senba K, Matsui T, Nishio N. Hydrogen and ethanol production from glycerol-containing wastes discharged after biodiesel manufacturing process. J Biosci Bioeng 2005;100(3):260-5.

[3] Zhou Q, Takenaka S, Murakami S, Seesuriyachan P, Kuntiya A, Aoki K. Screening and characterization of bacteria that can utilize ammonium and nitrate ions simultaneously 
under controlled cultural conditions. J Biosci Bioeng 2007;103: 185-91.

[4] Converti A, Perego P, Borghi MD. Effect of specific oxygen uptake rate on Enterobacter aerogenes energetics: carbon and reduction degree balances in batch cultivations. Biotechnol Bioeng 2003;82(3):370-7.

[5] Murarka A, Dharmadi Y, Yazdani SS, Gonzalez R. Fermentativeutilization of glycerol by Escherichia coli and its implications for the production of fuels and chemicals. Appl Environ Microbiol; 2008:1124-35.

[6] Seifert K, Waligorska M, Wojtowski M, Laniecki M. Hydrogen generation from glycerol in batch fermentation process. Int $J$ Hydrogen Energ 2009;34:3671-8.

[7] Selembo PA, Perez JM, Lloyd WA, Logan BE. Enhanced hydrogen and 1,3-propanediol production from glycerol by fermentation using mixed cultures. Biotechnol Bioeng 2009; 104:1098-106.

[8] Solomon BO, Zeng A-P, Biebl H, Ejiofor AO, Posten C, Deckwer WD. Effects of substrate limitation on product distribution and $\mathrm{H} 2 / \mathrm{CO} 2$ ratio in Klebsiella pnuemoniae during anaerobic fermentation of Glycerol. J Appl Microbiol Biot 1994;42:222-6.

[9] Temudo MF, Poldermans R, Kleerebezem R, Loosdrecht MCMv. Glycerol fermentation by (open) mixed cultures: a chemostat study. Biotechnol Bioeng 2008;100(6): 1088-98.

[10] Gonzแlez -PM, Meynial -SL, Mendes F, Andrade JC, Vasconcelos I, Soucaille P. Metabolic engineering of Clostridium acetobutylicum for the industrial production of 1,3-propanediol from glycerol. Metab Eng 2005;7:329-36.

[11] Taconi KA, Venkataramanan KP, Johnson DT. Growth and Solvent production by clostridium pasteurianum ATCCVVR 6013TM utilizing biodiesel-Derived crude glycerol as the Sole carbon Source. Environ Prog Sustainable Energy 2009;28(1): 100-10.
[12] Barbirato F, Himmi EH, Conte T, Bories A. 1,3-propanediol production by fermentation: an interesting way to valorize glycerin from the ester and ethanol industries. Ind Crops Prod 1998;7:281-9.

[13] Biebl H. Fermentation of glycerol by clostridium pasteurianum-batch and continuous culture studies. J Ind Microbiol Biot 2001;27:18-26.

[14] Biebl H. Glycerol fermentation of 1,3-propanediol by Clostridium butyricum. Measurement of product inhibition by use of a pH-auxostat. Appl Microbiol Biot 1991;35: 701-5.

[15] Saint-Amans S, Perlot P, Goma G, Soucaille P. High production of 1,3-propanediol from glycerol by Clostridium butyricum VPI 3266 in a simply controlled fed-batch system. Biotechnol Lett 1994;16(8):831-6.

[16] Liu F, Fang B. Optimization of bio-hydrogen production from biodiesel wastes by Klebsiella pneumoniae. Biotechnol J 2007;2: 374-80.

[17] Miller TL, Wolin MJ. A serum bottle modification of the Hungate technique for cultivating obligate anaerobes. Appl Microbiol 1974;27(5):985-7.

[18] Myers RH, Montgomery DC. Response Surface Methodology: process and product optimization using designed experiments. 2nd ed. Canada: John Wiley \& Sons, Inc.; 1995. 208-209.

[19] Tanisho S. Hydrogen production by facultative anaerobe Enterobacter aerogenes. In: Zaborsky, et al., editors. Biohydrogen. New York: Plenum Press; 1998. p. 273-9.

[20] Fabiano B, Perego P. Thermodynamic study and optimization of hydrogen production by Enterobacter aerogenes. Int J Hydrogen Energ 2002;27:149-56.

[21] Thompson JC, He BB. Characterization of crude glycerol from biodiesel production from multiple feedstocks. Appl Eng Agric 2006;22(2):261-5. 